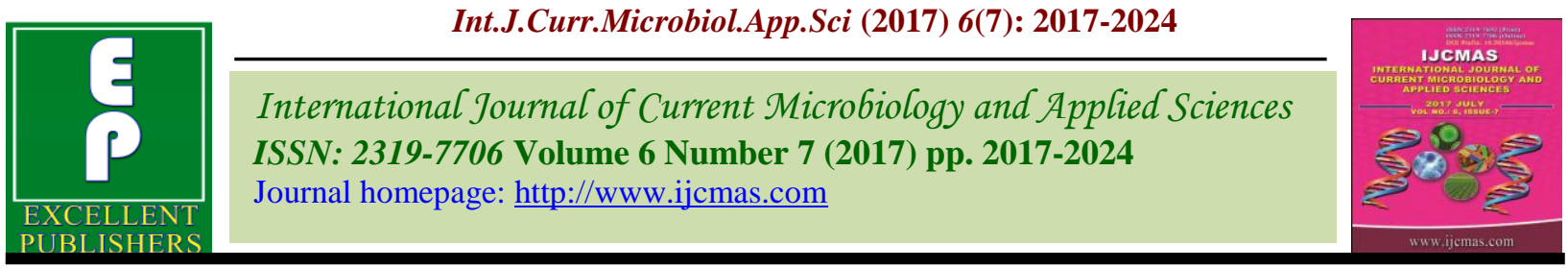

Original Research Article

https://doi.org/10.20546/ijcmas.2017.607.239

\title{
Biological Characterization of Okra Yellow Vein Mosaic Virus (OYVMV) Infecting Okra in South Gujarat, India
}

\author{
Tushar V. Ghevariya* and Lalit Mahatma \\ Department of Plant Pathology, NM College of Agriculture, \\ Navsari Agricultural University, Navsari - 396 450, Gujarat, India \\ *Corresponding author
}

\section{A B S T R A C T}

An experiment was conducted to characterize Okra Yellow Vein Mosaic Virus infecting Okra in south Gujarat region. Incidence of Yellow vein mosaic disease (YMD) of the okra ranging from 10-50 per cent in the different field of NAU as well as the adjoining area was observed during the survey in 2015 in late winter to summer. Total seven different fields of Okra in the villages around the Navsari Agricultural University, viz., Allu, Vankaner, Sejvad, Hathuka, Bhatlav, shiker and Delvada were surveyed. The crop grown in the

Keywords

Okra yellow vein mosaic virus, Grafting

Article Info

Accepted:

21 June 2017

Available Online:

10 July 2017 Vegetable Research Farm of NAU, Navsari in open fields was also surveyed. The disease appeared with the appearance of true leaves and was seen at all the stages of the growth. YMD in okra appeared with the appearance of true leaves and was seen at all the stages of the growth. The initial symptoms on young leaves were diffuse and mottled in appearance. Clearing of the small veins starts near the leaf margins, at various points however, were more pronounced towards the petiole end as compared towards the expanded margins of the leaf. Gradually the yellowing increases covering the interveinal area and entire leaf appeared yellow. In few cases the leaf tissue necrosis has also been reported. Fruit, stem and other above ground parts of the infected plants also turned yellow in color. Early infected plant remains dwarf. Market acceptability of the yellow colored fruits reduced severely causing enormous economic loss. In some of the plants no green colour symptoms were seen, however, had another type of symptoms principally characterized by the vein thickening. Plant if seen from the top or side, appeared rough, rugose, dark green and dwarfed. In case of severe infection the entire leaf crumpled, curled inside, petiole bend and even cannot hold leaf up. Swelling of the vein and enation can also be seen on the backside of the leaf. In graft transmission also the similar symptoms were observed, however, the vein thickenings were not observed.

\section{Introduction}

Okra (Abelmoschus esculentus L. Moench) belonging to the family Malvaceae is an important and extensively consumed vegetable crop of the tropical and subtropical region of the world. Crop is good source of fat, carbohydrate, fiber, $\mathrm{Ca}, \mathrm{P}, \mathrm{Fe}$, ascorbic acid, $\beta$-carotene, thiamin, riboflavin and niacin (Gopalan et al., 2007, Varmudy 2011). Among the different biotic and abiotic factors,
Yellow Vein Mosaic Disease (YVMD), caused by the Okra Yellow Vein Mosaic Virus (OYVMV) is the most serious constraints in the production of okra (Farnendo and Udurawana, 1942; Harender et al., 1993, Nath et al., 1993, Sastry and Singh, 1975). OYVMV characteristically have circular single-stranded DNA genomes packaged within twinned (so-called geminate) 
particles belongs to genus Begomovirus, family Geminiviridae (Lazarowitz 1992). The virus was first reported in 1924 from the erstwhile Bombay presidency in India (Kulkarni 1924). It is persistently transmitted by whitefly Bemisia tabaci (Gennadius) (Hemiptera: Aleyrodidae). Indirect seed transmission of Begomoviru,s specially Mungbean Yellow Mosaic Virus has also been reported (Pawar 2010, Pawar 2015, Mahatma and Pawar 2015). The incidence of virus in the field frequently reached even up 100 Per cent, which caused more than 95.5 Per cent yield reduction of fresh fruit (Pun et al., 1999). Graft transmission of almost all the viruses including Begomoviruses is possible; however, very little work has been done in the direction. There a report of the graft transmission of OYVMV by (Samarjeeva and Rathnayaka, 2004). Mahatma et al., (2007) observed 1.2 million tonnes fresh fruit losses to the tune of US \$ 134 million due to YVMD in India in assessment year 2003-04. The virus seems to attack okra plants in any stage of plant growth, spreads quickly in the field and adversely affects the growth and yield (Hossain et al., 1998). South Gujarat is one of the potential okra growing area where the crop is growing for the domestic market as well as export. Heavy incidences of the YVMD in the different okra growing area have been observed since last few years. Therefore, the present investigation was carried out to molecularly and biologically characterization the virus.

\section{Materials and Methods}

\section{Survey}

Occurrence of the disease in Navsari districts were observed by field surveys. Fields were selected randomly, disease was tentatively identified and incidence was observed on the basis of symptoms expressed by the virus. Disease incidence was calculated as per the method given by Mahatma and Pawar (2015). Each field was observed from all the four corners and centre for the assessment of disease incidence and get realistic picture of the spread of the disease in the field. From each side around 50 plants were selected and infected and apparently healthy plants were counted. Disease incidence (DI) was calculated by the dividing number of infected plants with the total number of plant and multiplying it with hundred. Representative samples were bought to the laboratory to confirm the pathogen by PCR.

\section{Symptomatology of diseases}

The symptoms of Okra Yellow Vein Mosaic Virus (OYVMV) were studied from the naturally infected Okra plants first in the field. Specific plant was collected and brought for grafting to the greenhouse. The infected plant was used as a scion and grafted on the susceptible seedling scion raised in the greenhouse and developments of the symptoms were observed in the grafted plants since beginning. Symptoms were also observed from the different field in and around Navsari Agricultural University farm, Navsari. Healthy uninfected plant of the same age was maintained for the comparison of the symptoms and its gradual changes.

\section{Graft transmission study}

Grafting was done as per the standard grafting protocol being used for the grafting of different plants in the horticulture. For the study of graft transmission, one plant was used as either scion or root stock from the selected healthy plant whereas another plant was selected as virus infected. Size of the both the plants stem was retained same for the uniform coverage of the excised area to facilitate union of the graft. Two different types of grafting viz., Approach and Side Veneer was used for the transmission study. 


\section{Approach grafting}

For the approach grafting both the healthy and infected plants were raised separately. Uniform size of healthy and infected plant was selected and approximately 2 inches bark (epidermis) along with small portion of cortex of the stem was excised vertically as given in the (Plate-1) from the healthy as well as infected plants.

Both the end were brought together and were tied with help of polythene ribbon tightly to hold in such a way that the excised portion of one is covered by the excised portion of another plant thoroughly. Some parts of the plant canopy from both the plants were removed to avoid the transpiration losses and also to stimulate the sprouting of lateral buds as the newly emerging sprouts and leaves shows clear and characteristics symptoms. Plants were kept in insect free greenhouse and were monitored for the development of the symptoms.

\section{Veneer grafting}

For the side veneer grafting small "V" shape notch around 2 inches deep in the side of the stem was made in such a way that it expose the cortex to cambium region of the stem from both the side without much damage to the vascular bundles of the root stock. Accordingly, a small portion of the actively growing scion was excised from the mother plant and bottom portion of the same was cut into wedge shape of such a length which firmly fixed into the "V" shaped notch of the root stock. Union was tied with help of polythene ribbon tightly (Plate-2). Some plant canopies from both the plants were removed to avoid the transpiration losses and also to stimulate the sprouting of lateral buds as the newly emerging sprouts and leaves shows clear and characteristics symptoms. Scion was covered with the perforated polybag to avoid moisture loss. Plants were kept in insect free greenhouse and were monitored for the development of the symptoms. In one set of the experiment the root stock was selected as healthy, whereas, the scion was infected. In another set the root stock was infected, whereas, the scion was selected as healthy. Development of the symptoms was observed in the healthy portion.

\section{Results and Discussion}

Heavy incidence of the disease in the different field of NAU as well as the adjoining area could be seen during the survey in 2015 during late winter to summer. Total seven different fields of Okra in the villages around the Navsari viz., Allu, Vankaner, Sejvad, Hathuka, Bhatlav, shiker and Delvada were surveyed. The crop grown in the Vegetable Research Farm of NAU, Navsari in open fields was also surveyed. Typical yellow vein mosaic symptoms were seen in all the area surveyed ranging from 10-50 per cent (Table 1). The variation in disease incidence was mainly due to the different stages of the crop at different place and the management practices followed. In every infected field surveyed, whiteflies were been found invariably.

However, jassids and thrips were the other insect pests noticed. Only one representative plant was selected and brought by uprooting it completely to the greenhouse for further study.

YMD in okra appeared with the appearance of true leaves and was seen at all the stages of the growth. The initial symptoms on young leaves were diffuse and mottled in appearance. Clearing of the small veins starts near the leaf margins, at various points however, were more pronounced towards the petiole end as compared towards the expanded margins of the leaf (plate-3.2\& 3.3). 

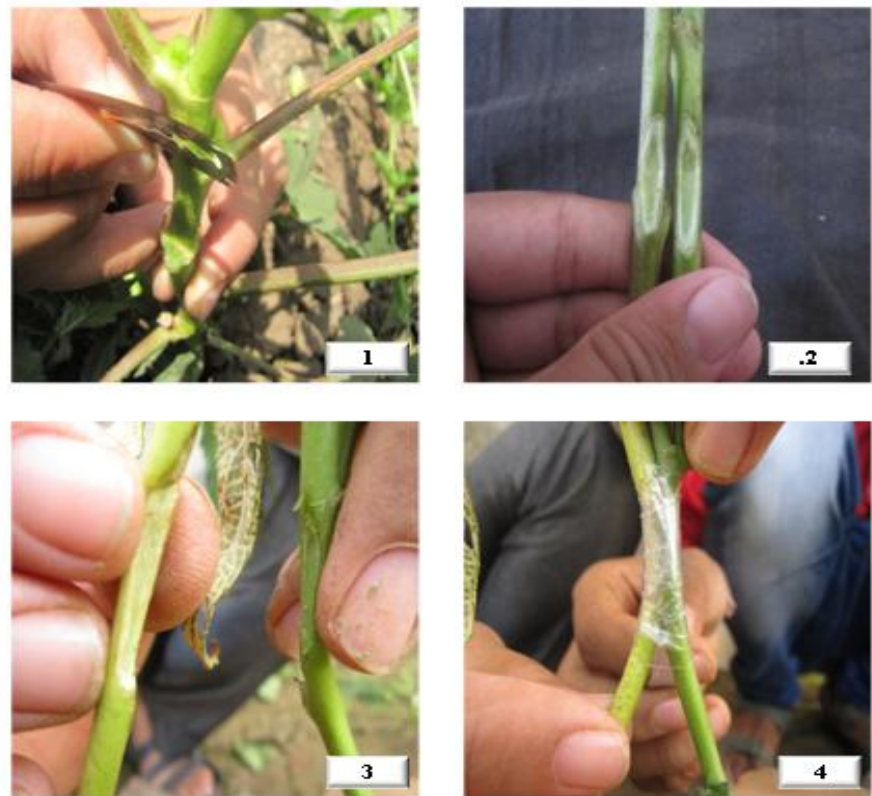

Plate-1 : Approach grafting.

1- Approx 2 inches excision

2- Excised portion from healthy and infected plant

3- Superimposing the cut regions

4- Air tight tied graft by polythene stip
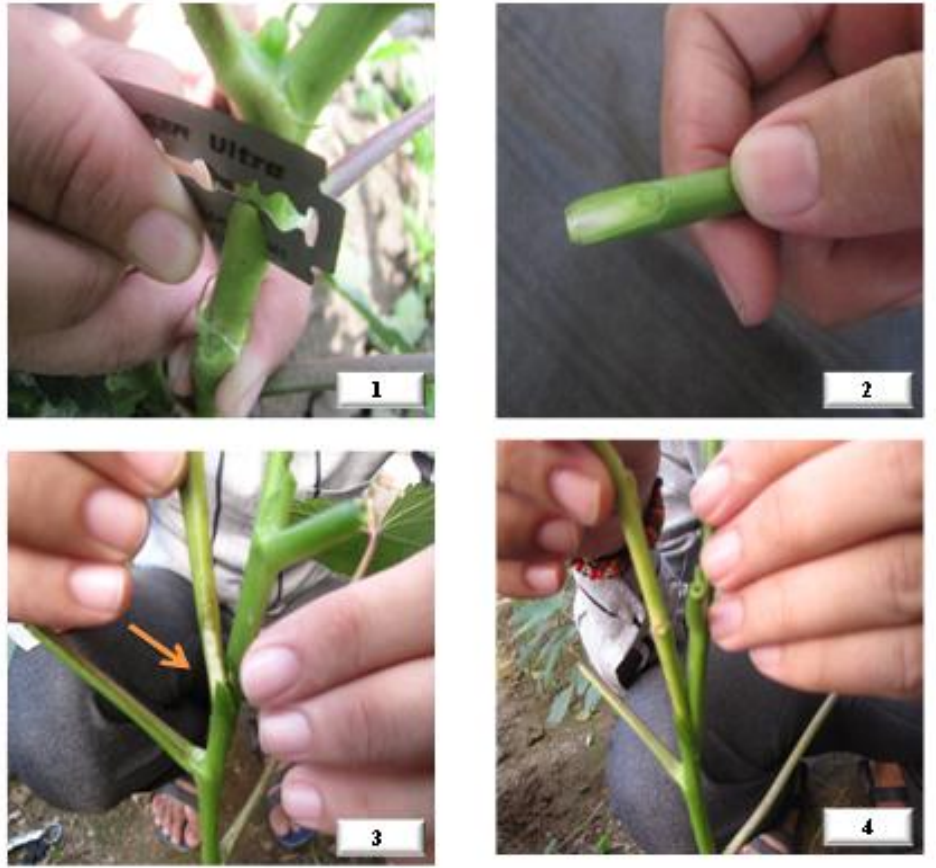

Plate- 2: Side veneer grafting.

1-"V" shape notch 2 inches depth notch on stock

2- Wedge shape scion

3-Insertion of wedge shaped scion

4- Air tight tied graftby polythene strip 

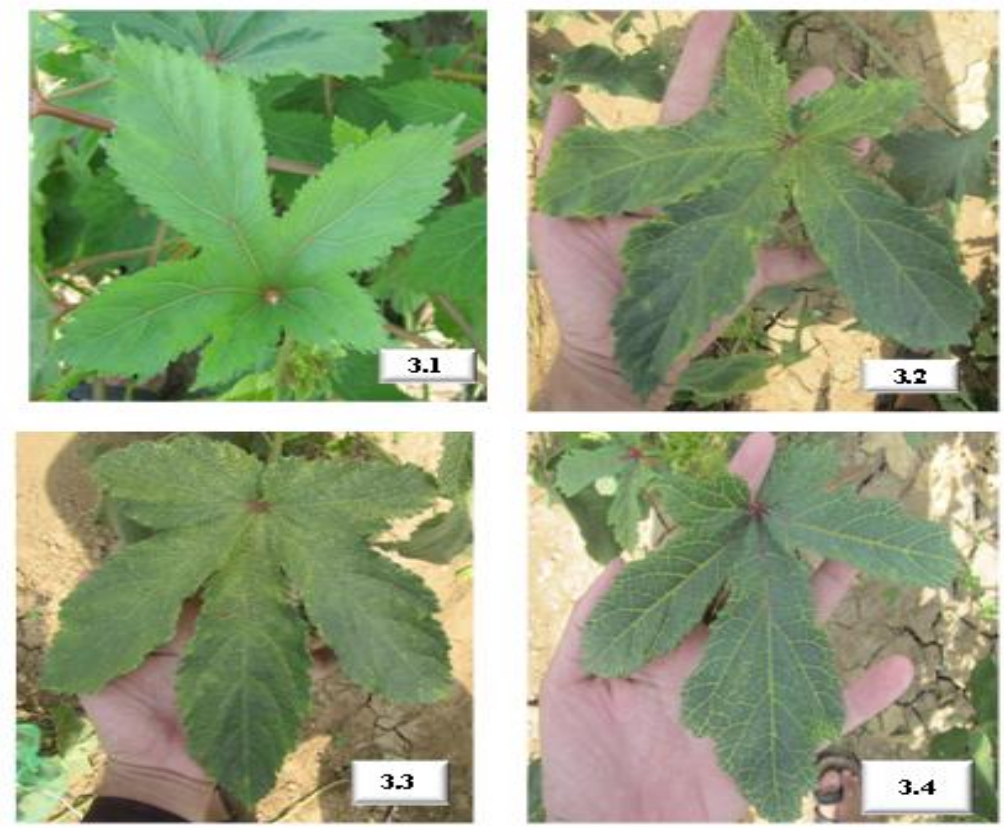

Plate-3: Symp toms ob served on okra plant d ue to Y VM V infection 3.1-Healthy leaf

3.2-Clearing of the small veins starting near the petiole end 33 -Veing clearing exp anding tow ards margins of the leaf 3.4-primary \& secondary vein's clearing \& chlorosis
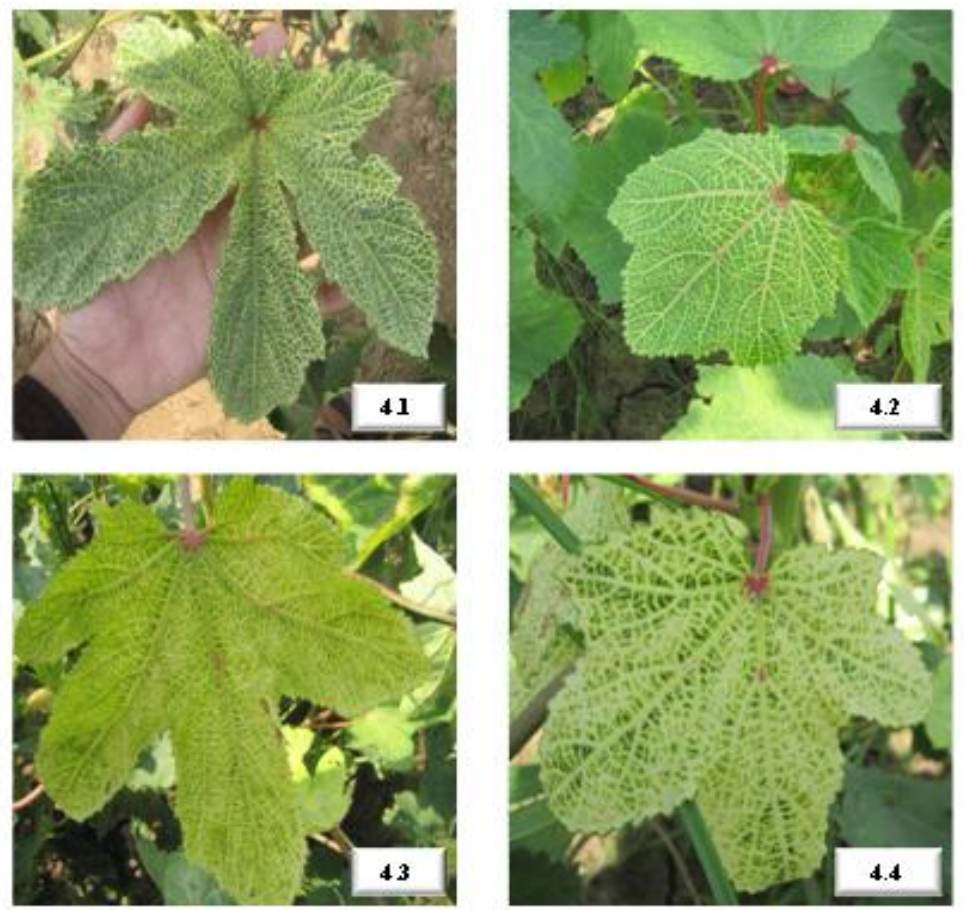

Plate-4: Symptoms observed on okra plant due to YVMV infection 4.1 - Interwoven network of yellow vein

4.2-Green tissue of leaf blade appearing as an Island 43 \&4.4 Increased area covering the interveinal region 

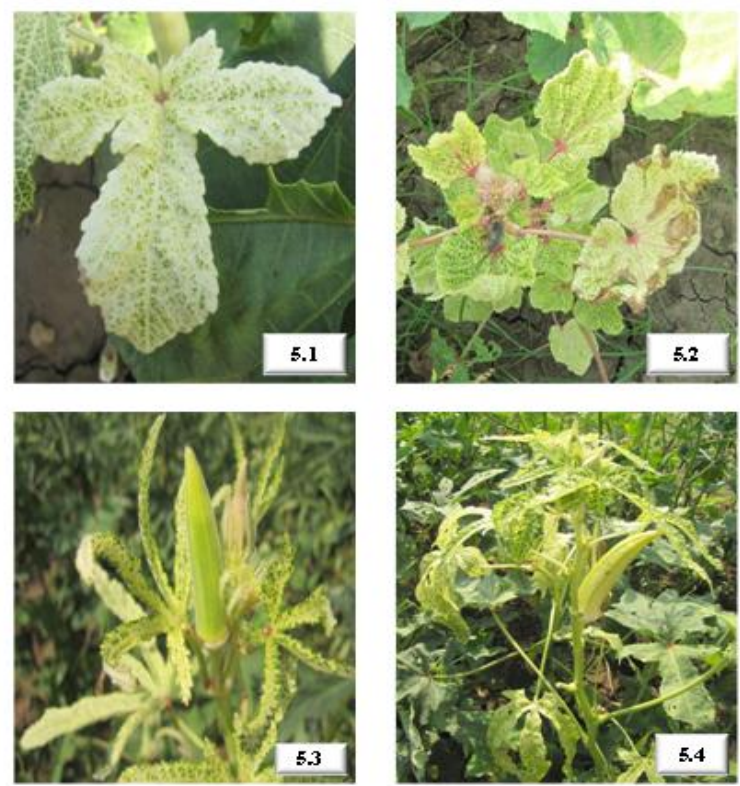

Plate-5: Symptoms observed on olra plant due to YVMV infection

5.1-Complete leaf yellowing

5.2- leaf tissue necrosis

5.3- Fruits h ave yellow, longitudin al alignment

5.4 fruits showing complete yellowing
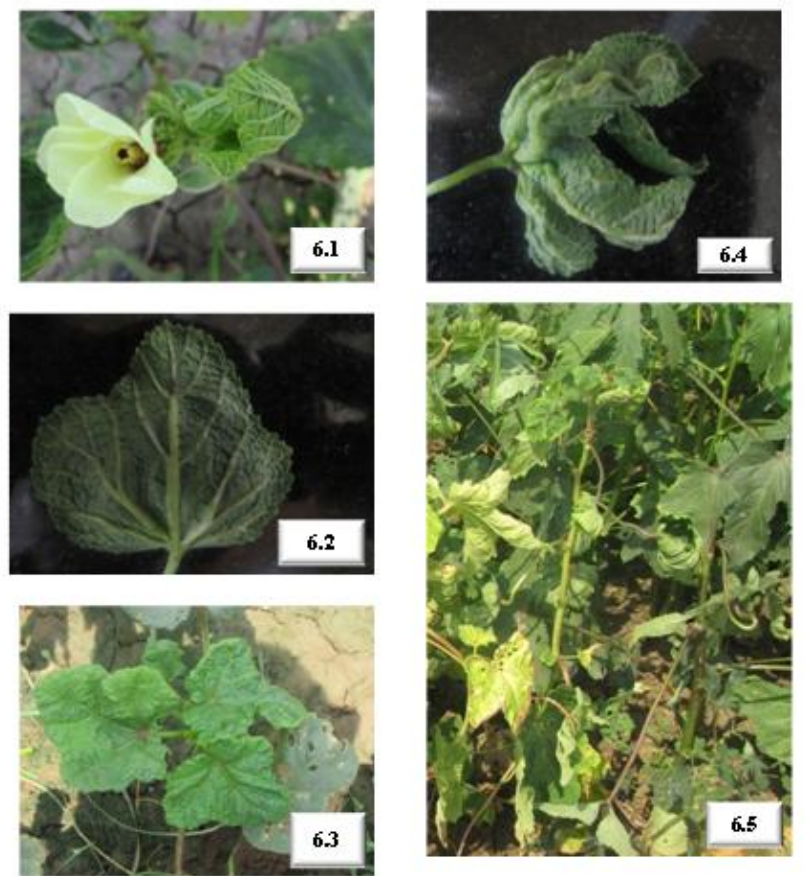

Plate-6: Symp toms ob served at on okra p lant due to YVM V infection 6.1-T he initial vein thickening of d ow $n$ side of the leaf 6.2- The vein thickening on entire leaf lam ina 63-Plant appearing rough, rugose, dark green and dwarfed

6.4- Crumpling curling and vein swelling on infected leaf 65- Petio le b anding 
Table.1 Survey of Okra Yellow Vein Mosaic Virus Disease incidence in Navsari during late winter to onset of summer of the year 2015

\begin{tabular}{|l|l|c|c|}
\hline S. No. & Village & $\begin{array}{c}\text { Stage of the crop } \\
\text { (days after sowing) }\end{array}$ & $\begin{array}{c}\text { Disease Incidence } \\
(\mathbf{\%})\end{array}$ \\
\hline 1. & Allu & 20 & 10 \\
\hline 2. & Vankaner & 50 & 10 \\
\hline 3. & Sejvad & 60 & 20 \\
\hline 4. & Hathuka & 70 & 50 \\
\hline 5. & Bhatlav & 60 & 20 \\
\hline 6. & Shiker & 70 & 30 \\
\hline 7. & Delvada & 80 & 40 \\
\hline 8. & NAU Farm & 40 & 15 \\
\hline
\end{tabular}

Thereafter, the vein clearing develops into a vein chlorosis covering almost all the primary and secondary veins (plate-3.4). The newly developed leaves exhibit an interwoven network of yellow vein, which enclose the green patches of the leaf (plate-4.1\& 4.2). Green tissue of the leaf blade appears like an Island. Gradually the yellowing increases covering the interveinal area and entire leaf appeared yellow (plate $-4.3,4.4 \& 5.1$ ). In few cases the leaf tissue necrosis has also been reported (plate-5.2). Fruits developing on infected plants have irregular yellow areas which followed a longitudinal alignment, malformed and reduced in size. In severe case fruits turned complete yellow and small (plate-5.3 \& 5.4). Stem and other above ground parts of the infected plants also turned yellow in color. Early infected plant remains dwarf. Market acceptability of the yellow colored fruits reduced severely causing enormous economic loss. In some of the plants no green colour symptoms were seen, however, had another type of symptoms principally characterized by the vein thickening. The initial symptoms appeared were vein thickening of the secondary of tertiary vein could be seen down side of the leaf. Gradually the vein thickening expanded in the leaf lamina (plate-6.1\&6.2). Plant if seen from the top or side, appeared rough, rugose, dark green and dwarfed (plate-6.3). In case of severe infection the entire leaf crumpled, curled inside, petiole bend and even cannot hold leaf up (plate-6.4). Swelling of the vein and enation can also be seen on the backside of the leaf (plate-6.5). The virus seems entirely different species/strain of the whitefly transmitted Geminivirus. The severity of the disease depended upon the stage of infection, varieties of the crop, strain of the virus, environmental factors and crop management practices followed by the farmers. In graft transmission also the similar symptoms were observed, however, the vein thickenings were not observed. This might be because of the strain and varietal interaction of the crop. Similar symptoms have been observed by (Brunt et al., 1990; Kucharek, 2004 and Doraiswarmy, 1999)

\section{References}

Anonymous. (2015). http://www.ictvonline. org/virusTaxonomy.asp page visited on 30.05.2015

Brunt, A., Crabtree, K. and Gibbs, A., (1990).Viruses of Tropical Plants. CAB International, Wallingford, UK.

Fernando, M. and Udurawana, S. B. (1942). The nature of the mosaic disease of Bandakka (Hibiscus esculentus L.).Tropical Agriculture (Ceylon). 98: 16-24.Focus 12, 13-15.

Gopalan C., Sastri S.B.V. and Balasubramanian S. (2007) Nutritive 
value of Indian foods, National Institute of Nutrition (NIN), ICMR, India

Harender, R., Bhardwaj, M. L., Sharma, I. M. and Sharma, N. K. (1993).Performance of commercial okra (Hibiscus esculentus) varieties in relation to disease and insect pests. Indian Journal of Agricultural Science.63 (11): 747748.

Hossain, A. B. M. S. (1998). Effect of intercropping on incidence of okra mosaic disease.MS thesis. Department of Plant Pathology, Bangladesh Agricultural University, Mymensingh.

Kucharek T. (2004). Florida plant disease management guide: Okra. Plant Pathology Department document PDMG-V3-41.Florida Cooperative Extension Service, Institute of Food and Agricultural Sciences, University of Florida, Gainesville, FL.

Lazarowitz, S. G. (1992). Geminiviruses: genome structure and gene function. Critical Rev. in Plant Sci., 11, 327-349. Mahatma L., Sajjan M., Naidu G.K., Deshpande A., Zehr U.B. and Ravi K.S. (2007). Distribution and yield losses due to Okra yellow vein mosaic virus in India Poster presented in $\mathrm{V}$ international Geminivirus Organized at Estalagem das Minas Gerais during, Brazil May 20-27.

Nath, P. D., Gupta, M. K. and Bora, P. (1993). Influence of sowing time on the incidence of yellow vein mosaic and whitefly (Bernisia (abaci) population on okra. Indian Journal of Virology.8 (1): 45-48.

Pun, K.B. and Doraiswamy, S. (1999). Effect of age of okra plants on susceptibility to Okra yellow vein mosaic virus. Indian journal of virology. 15: 57-58.

Pun, K.B., Doriswamy, S. and Jeyarajan, R. (1999). Screening plant species for the presence of antiviral principles against Okra yellow vein mosaic virus. Indian Phytopathology. 52(3): 221-223.

Samarajeewa P.K. and Rathnayaka RMUSK. (2004). Disease resistance and genetic variation of wild relatives of Okra (Abelmoschus esculentus L.). Annals of the Shri Lanka Department of Agriculture 6:167-176.

Sastry, K. S. M. and Singh, S. J. (1975).Yellow mosaic of Bhindi. Curr. Sci. 9: 227-228.

Varmudy V. (2011). Marking survey need to boost okra exports. Department of economics, Vivekananda College, Puttur, Karnataka, India.

\section{How to cite this article:}

Tushar V. Ghevariya and Lalit Mahatma. 2017. Biological characterization of Okra yellow vein mosaic virus (OYVMV) infecting okra in South Gujarat, India. Int.J.Curr.Microbiol.App.Sci. 6(7): 2017-2024. doi: https://doi.org/10.20546/ijcmas.2017.607.239 